\title{
Observation of intracellular bacterial communities in urinary sediment using brightfield microscopy; a case report
}

\author{
Carlos Martínez-Figueroa', Karen Cortés-Sarabia', Luz del Carmen Alarcón-Romero', \\ Hilda Guadalupe Catalán-Nájera², Micaela Martínez-Alarcón ${ }^{2}$ and Amalia Vences-Velázquez ${ }^{1 *}$
}

\begin{abstract}
Background: Urinary tract infections (UTIs) are usually related to the presence of Escherichia coli, a microorganism that adopts an intracellular life-style during the pathogenesis of cystitis. Evidence of the underlying mechanism in urothelial cells from urine samples has been reported. However, intracellular communities have not yet been described in squamous cells in fresh samples stained with Sternheimer-Malbin method, thus, we have provided these descriptions in this case report.

Case presentation: Number 1 was a male patient with symptoms of UTI, his urinalysis revealed hematuria and nitrites. In the urine sediment, we found urothelial cells with internal endosomes filled with short rods. Case number 2, female patient with recurrent UTI by E. coli, her urinalysis showed positive nitrites, glycosuria, bacteriuria and squamous cells with endosomes filled with short rods. Both patients were positive for $E$. coli isolation.

Conclusions: These case reports provide evidence of the presence of intracellular bacterial communities in urothelial and squamous cells (not previously reported) in fresh urine samples stained with Sternheimer-Malbin using brightfield microscopy. The clinical impact and pathogenic mechanisms involved in the invasion of the squamous epithelium need further investigation.
\end{abstract}

Keywords: Urinary tract infections, Escherichia coli, Intracellular bacterial communities, Urinary sediment, Case report

\section{Background}

Escherichia coli is the main etiological agent associated with urinary tract infections (UTIs). This microorganism is perfectly adapted to the environment of the urinary system. During the pathogenesis of cystitis, this bacteria use the intracellular route to form an intracellular biofilm, named as intracellular bacterial community (IBC), that has been studied in both in vivo and in vitro models $[1,2]$. IBCs are formed in superficial urothelial cells, they go through several maturation stages leading to biofilm

\footnotetext{
*Correspondence: ameliavences.v@uagro.mx

'Laboratorio de Inmunobiología y Diagnóstico Molecular, Facultad de Ciencias Químico Biológicas, Universidad Autónoma de Guerrero, Av. Lázaro Cárdenas s/n, University City, C.P.39090 Chilpancingo, Guerrero, Mexico Full list of author information is available at the end of the article
}

reorganization before differentiating into the filamentous and coccoid morphotypes commonly found in the late intracellular community $[2,3]$. Only a few cases on the presence of IBCs in urothelial cells of patients with UTI have been reported. Here, we report two new cases involving not only urothelial cells but also squamous cells.

\section{Case presentation \\ Patients information Case number 1}

A 50-year-old male patient, without any background of chronic or infectious diseases, urinary stones, or anatomical abnormalities, came to the hospital's emergency room with pelvic pain but no fever, vomiting or chills.

(c) The Author(s). 2020 Open Access This article is licensed under a Creative Commons Attribution 4.0 International License, which permits use, sharing, adaptation, distribution and reproduction in any medium or format, as long as you give appropriate credit to the original author(s) and the source, provide a link to the Creative Commons licence, and indicate if changes were made. The images or other third party material in this article are included in the article's Creative Commons licence, unless indicated otherwise in a credit line to the material. If material is not included in the article's Creative Commons licence and your intended use is not permitted by statutory regulation or exceeds the permitted use, you will need to obtain permission directly from the copyright holder. To view a copy of this licence, visit http://creativecommons.org/licenses/by/4.0/ The Creative Commons Public Domain Dedication waiver (http://creativecommons.org/publicdomain/zero/1.0/) applies to the data made available in this article, unless otherwise stated in a credit line to the data. 
Reported symptoms included dysuria, polaquiuria, hematuria and foul smelling urine.

\section{Case number 2}

A 64-year-old patient, with a background of diabetes mellitus, hypertension and hyperthyroidism, came to the bacteriological service area of the hospital's emergency room for controlling a recurrent UTI. No additional symptoms were reported. During the follow up, the patient showed a few episodes of healing and relapse.

\section{Diagnostic assessment}

For urinalysis, $10 \mathrm{~mL}$ of urine were aliquoted in a $16 \times$ $150 \mathrm{~mm}$ tube. Chemical tests were performed using test strips (SPINREACT URIN-10). After chemical testing, urine was centrifuged for $5 \mathrm{~min}$ at $450 \mathrm{~g}$, supernatant was aspirated using a pipette until $0.5 \mathrm{~mL}$ was left and $50 \mu \mathrm{L}$ of Sternheimer-Malbin dye was added. The Sternheimer-Malbin stain is a supravital dye composed by safranin $\mathrm{O}$ and cristal violet, is used to contrast the formed elements and to stain structures that have lost their vitality. Finally, sediments were examined under a brightfield microscope at $40 \times$ magnification.

\section{Case number 1}

Nitrites and hematuria (>100 erythrocytes/field) were confirmed by chemical and microscopic analyses of the patient's urine sample. In the sediments, superficial urothelial cells, along with scarce squamous cells, monohydrate calcium oxalate, and moderate bacteriuria including two bacterial morphotypes (short rods and filamentous forms) were observed, whereas noleukocytes were found. In the interior of an endosome from a superficial urothelial cell, we observed the presence of moving short rod bacteria (Fig. 1) (supplementary material 1$)$.

\section{Case number 2}

Nitrites and glycosuria were confirmed by chemical analysis of the patient's urine sample. In the sediment test, we observed bacteriuria, leukocyturia (5-10/field), and squamous cells with endosome-containing bacteria. Moving along different focus planes in the microscope, we were able to determine that short rods were in the interior of the cells and not in their surface. This location was confirmed in at least ten squamous cells along the sediment preparation (Fig. 2).

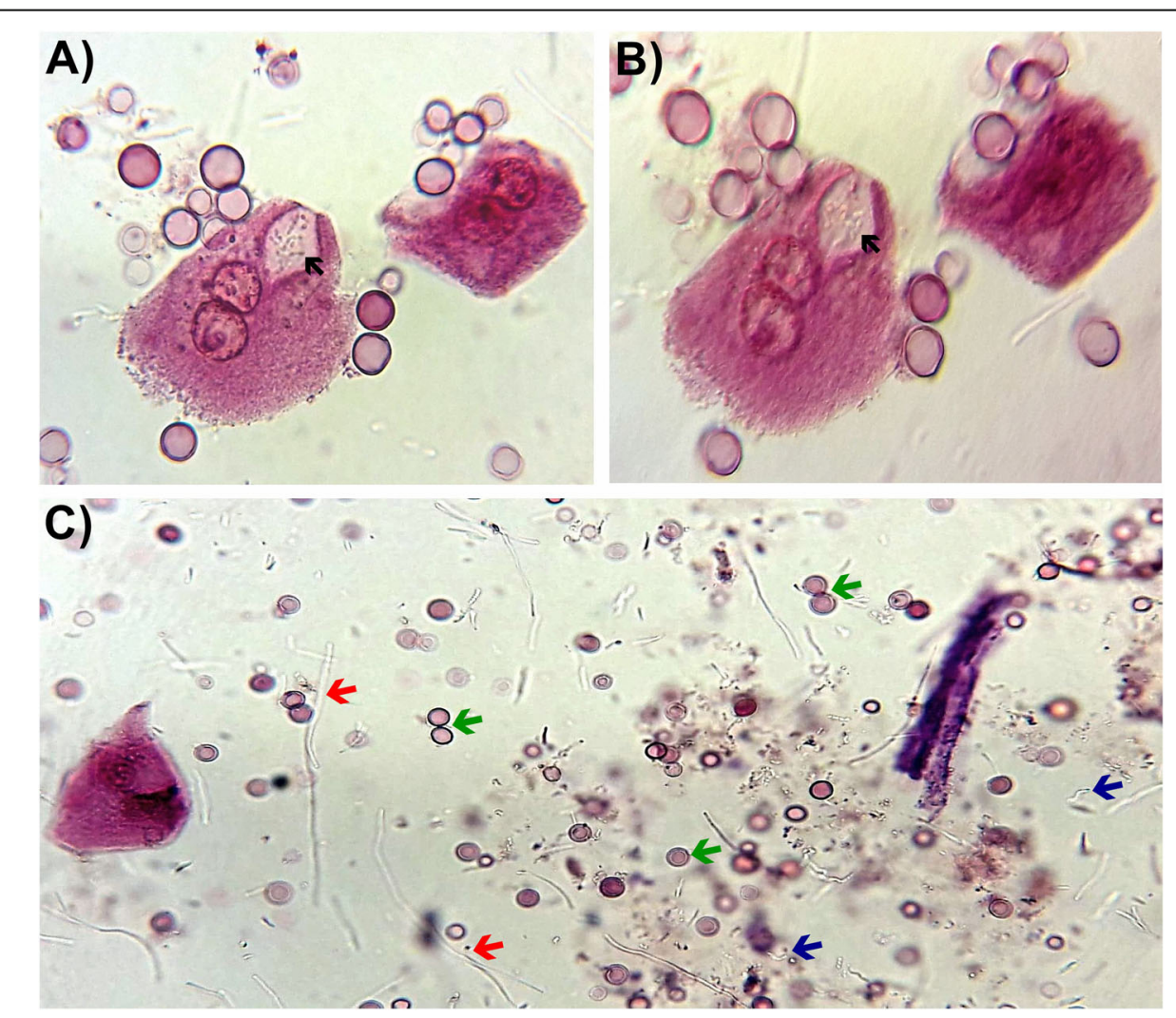

Fig. 1 Representative image of the urinary sediment of a patient with E. coli infection. a Clear field microscopy and $\mathbf{b}$ clear field microscopy with cylinder-type illumination images. Note the presence of urothelial cells with bacteria inside an endosome (black arrows). c Bright field microscope image showing different bacterial morphotypes, short (blue arrows) and long (red arrows) rods, and hematuria (green arrows). Images are at a 40x magnification 

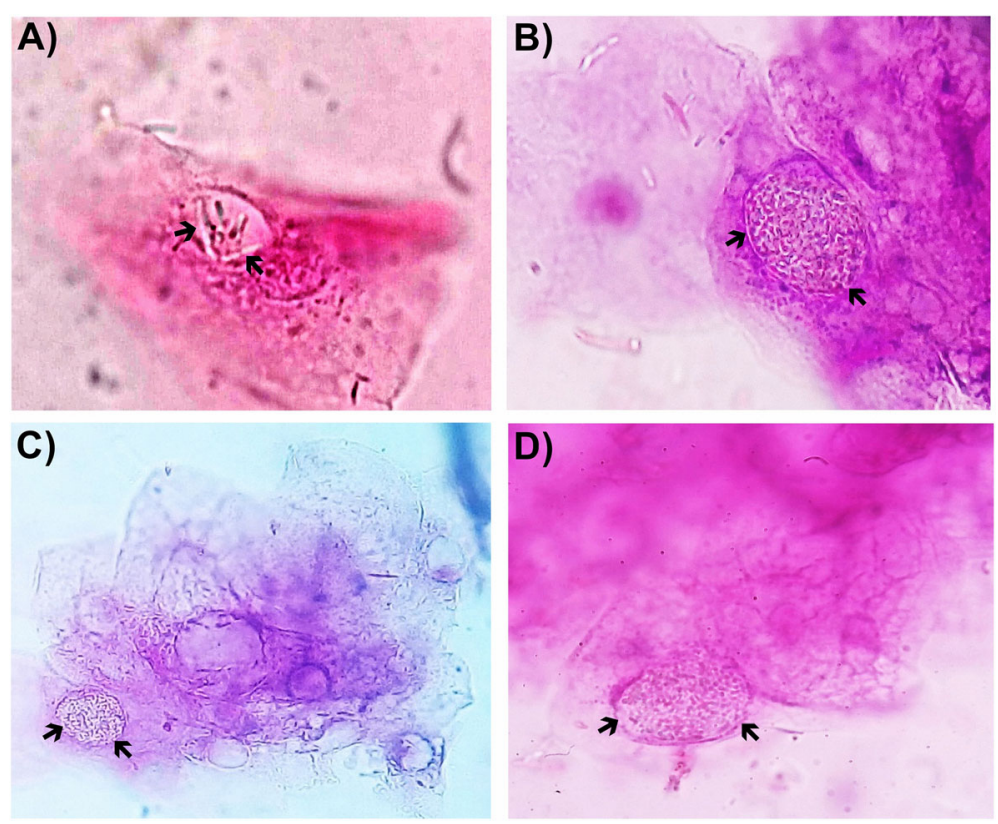

Fig. 2 Intracellular bacteria in the urinary sediment. a-d Bright field microscope image showing squamous cells with bacteria inside an endosome (black arrows). The sample was stained using the Sternheimer-Malbin method. The image is at $40 \times$ magnification

\section{Diagnostic}

For both cases, we isolated $E$. coli with colony counts greater that $>100,000 \mathrm{UFC} / \mathrm{mL}$.

\section{Discussion and conclusions}

IBC formation is a protective mechanism of invasion of the bladder by $E$. coli. It has been reported that biofilm formation is related with the evasion of the host innate immune response, antibiotic resistance, and urinary tract persistence $[3,4]$. However, there are just a few reports about the presence of IBCs in the urine of patients with cystitis. Rosen et al. (2007), reported the existence of IBC-like structures in women with cystitis, these structures were similar to those exfoliated intracellular communities observed in the urine of mice with cystitis, and that this pathogenic route could be implicated in the recurrence of the infection [5]. Whereas, Robino et al. (2014) found IBCs in 36.8\% of a population of children with urinary tract infections by $E$. coli. The presence of these IBCs was associated with recurrent infections in patients without morphological or structural abnormalities in their urinary tracts [6].

The squamous epithelium is found in the bladder trigone and the urethra in both sexes. The presence of IBCs in squamous cells could indicate that there is an infection in any of these sites, an infection that may have not been previously described. In the contrary, IBC formation in urothelial cells is generally related to know infections. Consequently, further investigation to establish pathogenic mechanism mediating IBC formation in squamous cells and its contribution to the development of cystitis is needed [2, 7].
According to our findings, the contributions of this study to the field of UTIs are listed as follows: A) The presence of IBCs in fresh samples can be determined using Sternheimer-Malbin stain and brightfield microscopy, instead of electronic microscopy of confocal microscopy and Giemsa stain, as reported previously; B) IBC may form in squamous cells (case 2), a bacterial protection mechanism that had only been found in urothelial cells $[1,2]$, indicating that squamous epithelium could be infected; and C) The filamentous morphotype of $E$. coli, which has been associated with phagocytosis evasion by polymorphonuclear cells and an increase in adherence points, can be found in urothelial cells. It is known that, during the pathogenic cycle, filamentous bacteria fragmentate to form short rods that mediate the invasion of superficial cells and contribute to the recurrence of the infection through the invasion of basal urothelial cells and the formation of quiescent intracellular reservoirs associated with chronic infections $[2,8,9]$.

A urinary sediment analysis is conventionally used to search for crystals, cylinders, and cells in urine samples. However, it may also be a useful tool in the search of the mechanism of pathogenesis of different microorganism because results, such as intracellular invasion could explain the recurrence of an infection and the failure of an antibiotic treatment. It would be important to determine the prognostic value of IBCs and bacterial morphotypes in urinary tract infections and their clinical significance as well as to explore those intracellular pathways that allow the adaptation of IBCs to squamous cells. 


\section{Supplementary information}

Supplementary information accompanies this paper at https://doi.org/10. 1186/s12894-020-00661-y.

\section{Additional file 1.}

\section{Abbreviations}

E. coli: Escherichia coli; IBC: intracellular bacterial communities; UTI: Urinary tract infections

\section{Acknowledgements}

We are very grateful to María Ruiz Rosas for all the contributions and technical support.

\section{Authors' contributions}

CMF and LDCAR evaluated urine sediments, made contributions to data collection, literature search and they wrote the report. KCS and AW reviewed and edited the manuscript, also participated in study design. HGCN and MMA literature research, and performed microbiological diagnosis. We state that all authors have read and approved the manuscript.

\section{Funding}

This work was supported by the PFCE founding granted to the UAGro in 2018. The funding body did not play any roles in the design of the study and collection, analysis, and interpretation of data and in writing the manuscript.

\section{Availability of data and materials}

All the used protocols and materials will be provided after an e-mail to the correspondence author.

\section{Ethics approval and consent to participate}

A written consent was obtained from the patients for publication of this case report and any accompanying images. The consent was written based on the Helsinki declaration of 2013. Also, the Ethics committee of the Universidad Autónoma de Guerrero approved the study.

\section{Consent for publication}

A copy of the written consent is available for review.

\section{Competing interests}

The authors declare that they have no competing interests.

\section{Author details}

${ }^{1}$ Laboratorio de Inmunobiología y Diagnóstico Molecular, Facultad de Ciencias Químico Biológicas, Universidad Autónoma de Guerrero, Av. Lázaro Cárdenas s/n, University City, C.P.39090 Chilpancingo, Guerrero, Mexico. ${ }^{2}$ Servicio de urgencias, Laboratorio clínico, Clínica Hospital ISSSTE, Iguala, Guerrero, Mexico.

Received: 7 April 2020 Accepted: 26 June 2020

Published online: 06 July 2020

\section{References}

1. Justice SS, Hung C, Theriot JA, Fletcher DA, Anderson GG, Footer MJ, et al. Differentiation and developmental pathways of uropathogenic Escherichia coli in urinary tract pathogenesis. Proc Natl Acad Sci. 2004;101(5):1333-8.

2. Andersen TE, Khandige S, Madelung M, Brewer J, Kolmos HJ, Møller-Jensen J. Escherichia coli Uropathogenesis in vitro: invasion, cellular escape, and secondary infection analyzed in a human bladder cell infection model. Infect Immun. 2012;80(5):1858-67.

3. Anderson GG, Palermo JJ, Schilling JD, Roth R, Heuser J, Hultgren SJ. Intracellular Bacterial Biofilm-Like Pods in Urinary Tract Infections. Science. 2003;301(5629):105-7.

4. Mulvey MA, Schilling JD, Hultgren SJ. Establishment of a persistent Escherichia coli reservoir during the acute phase of a bladder infection. Infect Immun. 2001:69(7):4572-9.

5. Rosen DA, Hooton TM, Stamm WE, Humphrey PA, Hultgren SJ. Detection of intracellular bacterial communities in human urinary tract infection. PLoS Med. 2007;4(12):e329.
6. Robino L, Scavone P, Araujo L, Algorta G, Zunino P, Pírez MC, et al. Intracellular bacteria in the pathogenesis of Escherichia coli urinary tract infection in children. Clin Infect Dis. 2014;59(11):e158-64.

7. Pawnila W. Ross Histología Texto y Atlas: correlación con biología molecular y celular. 7th ed. China: Wolters Kluwer; 2015.

8. Justice SS, Hunstad DA, Seed PC, Hultgren SJ. Filamentation by Escherichia coli subverts innate defenses during urinary tract infection. Proc Natl Acad Sci. 2006;103(52):19884-9.

9. Schwartz DJ, Chen SL, Hultgren SJ, Seed PC. Population dynamics and niche distribution of uropathogenic Escherichia coli during acute and chronic urinary tract infection. Infect Immun. 2011;79(10):4250-9.

\section{Publisher's Note}

Springer Nature remains neutral with regard to jurisdictional claims in published maps and institutional affiliations.

\section{Ready to submit your research? Choose BMC and benefit from:}

- fast, convenient online submission

- thorough peer review by experienced researchers in your field

- rapid publication on acceptance

- support for research data, including large and complex data types

- gold Open Access which fosters wider collaboration and increased citations

- maximum visibility for your research: over $100 \mathrm{M}$ website views per year

At BMC, research is always in progress.

Learn more biomedcentral.com/submission 